\title{
PERNIKAHAN HAMIL DI LUAR NIKAH DALAM PERSPEKTIF KOMPILASI HUKUM ISLAM (KHI) DAN FIQIH ISLAM DI KANTOR URUSAN AGAMA (STUDI KASUS DI KOTA KUPANG)
}

\author{
Aladin \\ Program PascaSarjana Universitas Nusa Cendana \\ aladintesis46@gmail.com
}

\begin{abstract}
Pregnant marriage is an act that is basically not recommended by religion, because religion teaches people to virtue, but this practice is still a lot we encounter in society. The problems in this study are: (1) Why is there difference of marriage of pregnant marriage between Compilation of Islamic Law (KHI) and Islamic Law (HI) ?; (2) What is the legal status of marriage law of pregnant women due to adultery with men who impregnate her according to Islamic Law Compilation (KHI) and Islamic fiqih?.The conclusions of this study: first According to KHI that women who become pregnant out of wedlock can be directly married to men who impregnate her without waiting for the woman to give birth to her ingredients. Second, KHI allows to marry pregnant women due to adultery with men who impregnate him, according to Islamic law the legal status of marriage of pregnant women due to adultery with men who impregnate him there is a difference of opinion among the four schools.
\end{abstract}

Keywords: Pregnancy Marriage, KHI, Fiqh Islam.

\begin{abstract}
Abstrak
Hamil diluar nikah adalah tindakan yang pada dasarnya sangat tidak dianjurkan oleh agama, karena agama mengajarkan manusia pada kebajikan, namun demikian praktek ini masih banyak kita jumpai di masyarakat.Masalah dalam penelitian ini adalah: (1) Mengapa terjadi perbedaan mengenai pernikahan hamil di luar nikah antara Kompilasi Hukum Islam (KHI) dan Hukum Islam (HI)?; (2) Bagaimana status hukumpernikahanwanitahamilakibatzinadenganlaki-laki yang menghamilinyamenurutKompilasi Hukum Islam (KHI)danfiqih Islam?.Kesimpulan dari penelitian ini adalah: pertama,menurut KHI bahwa wanita yang hamil di luar nikah bisa langsung di nikahkan dengan laki-laki yang menghamilinya tanpa menunggu wanita itu melahirkan kandugannya. Kedua, KHI membolehkan menikahi wanita hamil akibat zina dengan laki-laki yang menghamilinya. Mazhab Hanafi dan Syafi'i membolehkan pernikahan wanita hamil akibat zina dengan laki-laki yang menghamilinya. Mazhab Maliki dan Hanbali melarang pernikahan wanita hamil akibat zina dengan laki-laki yang menghamilinya.
\end{abstract}

Kata Kunci: Pernikahan Hamil, KHI, Fiqih Islam.

\section{A. Pendahuluan}

Ketentuan UU Nomor 1 Tahun 1974 tentang Perkawinan (LNRI Th 1974 No. 1; TLN No. 3019) (Pasal 1 Undang-Undang Nomor 1 tahun 1974 tentang Perkawinan, Kementerian Agama Republik Indonesia) menetapkan, bahwa "Perkawinan ialah ikatan lahir bathin antara seorang pria dengan seorang wanita sebagai suami isteri dengan tujuan membentuk keluarga (rumah tangga) yang bahagia dan kekal berdasarkan Ketuhanan Yang Maha Esa." Dalam penjelasan ketentuan Pasal 1 UU
Perkawinan itu dijelaskan, bahwa: Sebagai Negara yang berdasarkan Pancasila, dimana sila yang pertamanya ialah Ketuhanan Yang Maha Esa, maka perkawinan mempunyai hubungan yang erat sekali dengan agama/kerohanian sehingga perkawinan bukan saja mempunyai peranan yang penting. Membentuk keluarga yang bahagia rapat hubungan dengan keturunan, yang pula ${ }_{2}$ merupakan tujuan perkawinan, Pemeliharaan dan Pendidikan menjadi hak dan kewajiban orang tua.Berdasarkan Penjelasan itu, perkawinan bukan sekedar 
hubungan yang bersifat perdata belaka, tetapi mengandung dimensi agama atau kerohanian yang mengimplikasikan bekerjanya peran agama dalam kehidupan keluarga, termasuk dalam pemeliharaan dan pendidikan dalam keluarga. Penjelasan itupun menekankan peran agama dalam keluarga dalam kaitan dengan hak dan kewajiban orang tua, sehingga orang tua harus merawat dan mendidik anak-anaknya sesuai dengan agama yang dianutnya.

Allah menetapkan pernikahan sebagai wahana membangun rumah tangga Islami. Dengan pernikahan, pergaulan antara pria dan wanita sebagai suami isteri terjalin dengan terhormat, hasrat psikis biologis tersalurkan, kepuasan dan kebahagiaan psikis emosional dapat tercapai sesuai fitrah dan kodrat insasni. Pernikahan mempunyai beberapa tujuan, di antaranya adalah untuk memenuhi kebutuhan hidup jasmani (kebutuhan biologis) dan rohani, sekaligus untuk membentuk keluarga yang merupakan sarana untuk meneruskan dan memelihara keturunan yang jelas, karena Islam sangat menjaga kemurnian keturunan (Khoirudin Nasution, 2004).

Pernikahan wanita hamil akibat zina dipengaruhi oleh faktor yang sangat kompleks antara lain: kondisi ekonomi, latar belakang pendidikan, interaksi sosial, dan pemahaman nilai terhadap norma-norma agama. Akibat dari ketidakmampuan ini banyak remaja berani melakukan hubungan badan sebelum menikah.

Berbeda dengan mahluk-mahluk Allah yang lain, dalam mendapatkan pasangannya manusia dikenakan syarat-syarat khusus. Syarat-syarat tersebut terkumpul dalam sebuah akad yang dinamakan pernikahan. Tentunya perbedaan ini disebabkan karena Allah telah memberikan keistimewaan yang sangat besar kepada manusia, yaitu akal dan hati. Diharapakan pula dengan akal dan hati tersebut manusia dapat menemukan pasangannya secara halal dan bisa menjadi pasangan yang sakinah, mawaddah dan warahmah.

Pernikahan sangat dianjurkan oleh agama sebagaimana banyak termuat dalam al-Qur'an dan al-Hadis. Ini seperti pendapat
Hasbi Ash-Shiddieqy dalam bukunya Hukum-Hukum Fiqh Islam ketika memberikan pengertian tentang pernikahan yaitu "Nikah, suatu aqad syar'i (ikatan keagamaan) yang dianjurkan Syara" (AshShiddieqy, Hasbi, 1978).

Kompilasi Hukum Islam (KHI) memberikan pengertian tentang pernikahan atau perkawinan dalam Pasal 2 "yaitu akad yang sangat kuat atau mitsaqan ghalidzan untuk mentaati perintah Allah dan melaksanakannya merupakan ibadah" (Departemen Agama RI, 2000). Yang dituntut oleh agama adalah perkawinan yang sah. Karena dengan perkawinan yang sah itu diharapakan dapat terwujud keluarga yang sakinah, mawaddah dan warahmah. Dengan mensyariatkan nikah, tentunya Allah juga mempunyai tujuan-tujuan. Dalam hal ini Yusuf Qadwhawi mengungkapkan, kalau sekiranya perkawinan itu tidak disyariatkan, tentu naluri seksual tidak dapat tersalurkan dan tidak dapat memainkan perannya dalam menjaga eksistensi manusia. Kalau sekiranya zina itu tidak diharamkan, hubungan seksual tidak dibatasi hanya oleh laki-laki dan wanita tertentu yang diikat tali pernikahan, niscaya tidak terwujudlah keluarga yang membangun perasaan sosial yang luhur, berupa cinta dan kasih sayang. Kalau tidak ada keluarga tentu tidak terbentuk suatu masyarakat, bahkan tidak ada usaha ke arah yang lebih baik lagi sempurna (Qardhawi, Yusuf, 2003).

Persoalanya, bahwa dalam realitas kehidupan masyarakat tidak dapat dihindari adanya hamil di luar nikah. Hamil di luar nikah adalah tindakan yang pada dasarnya sangat tidak dianjurkan oleh agama, karena agama mengajarkan manusia pada kebajikan, namun demikian praktek ini masih banyak kita jumpai di masyarakat.

Kecamatan Alak dan Kecamatan Kelapa Lima merupakan salah satu kecamatan yang masyarakatnya banyak menganut agama Islam, sehingga kedua kecamatan ini banyak melakukan/pencatatan peristiwa-peristiwa nikah secara Islam. Adapun data-data peristiwa nikah yang dilakukan tiga tahun terakhir sebagai berikut: 
Pada tahun 2013 tercatat 170 peristiwa nikah di kecamatan Kelapa Lima dengan rincian 143 peristiwa adalah pernikahan hamil di luar nikah, dan 27 peristiwa adalah perawan. Pada tahun 2014 tercatat 163 peristiwa nikah dengan rincian 140 peristiwa pernikahan hamil diluar nikah, 23 peristiwa adalah perawan. Pada tahun 2015 tercatat ada 160 peristiwa nikah dengan rincian 140 pernikahan hamil diluar nikah, dan hanya 20 peristiwa saja dikategorikan perawan.

Demikian halnya dengan kecamatan Alak. Data tiga tahun terakhir menunjukkan bahwa banyak sekali peristiwa nikah pernikahan hamil di luar nikah yang tercatat di kecamatan Alak. Pada tahun 2013 tercatat 110 peristiwa nikah dengan rincian 85 peristiwa adalah pernikahan hamil diluar nikah, 25 peristiwa adalah perawan. Pada tahun 2014 tercatat 130 peristiwa nikah dengan rincian 120 peristiwa adalah pernikahan hamil di luar nikah dan 10 peristiwa adalah perawan. Pada tahun 2015 tercatat 120 peristiwa nikah dengan rincian 100 peristiwa adalah pernikahan hamil di luar nikah, 20 peristiwa adalah perawan. Tujuan yang akan dicapai adalah untuk mengetahui perbedaan mengenai pernikahan hamil di luar nikah antara Kompilasi Hukum Islam (KHI) dan Hukum Islam (HI) dan status hukum pernikahan wanita hamil akibat zina dengan laki-laki yang menghamilinya menurut Kompilasi Hukum Islam (KHI) dan fiqih Islam. Permasalahan yang diajukan adalah :

1. Mengapa terjadi perbedaan mengenai pernikahan hamil di luar nikah antara Kompilasi Hukum Islam (KHI) dan Hukum Islam (HI)?

2. Bagaimana status hukum pernikahan wanita hamil akibat zina dengan lakilaki yang menghamilinya menurut Kompilasi Hukum Islam (KHI) dan fiqih Islam?

Jenis penelitian ini adalah penelitian yuridis normatif. Metode pendekatan yang digunakan adalah pendekatan studi kasus, konseptual, doktrinal/undang-undang, yuridis empiris. Jenis data terdiri dari data primer dan data sekunder. Data primer adalah data yang diperoleh langsung dari tempat penelitian yang berasal dari responden melalui wawancara langsung yang berpedoman pada daftar pertanyaan yang telah dipersiapkan maupun dalam bentuk dokumen tidak resmi yang kemdian diolah peneliti. Data sekunder adalah data yang diperoleh dari dokumen-dokemen resmi, baik berupa buku yang berhubungan dengan objek penelitian, hasil penelitian dalam bentuk laporan, skripsi, tesis, disertasi, jurnal, dan peraturan perundangan.

Bahan hukum primer adalah bahanbahan hukum yang mengikat, terdiri dari peraturan perundangan yang terkait dengan obyek penelitian. Bahan hukum sekunder adalah buku-buku dan tulisan-tulisan ilmiah yang terkait pula dengan obyek penelitian ini. Bahan hukum tertier adalah petunjuk atau penjelasan mengenai hukum primer atau bahan hukum sekunder yang berasal dari kamus, ensiklopedia, majalah, surat kabar dan sebagainya. Bahan hukum yang diperoleh selanjutnya diolah menggunakan metode Editing, Codding, Pentabulasian, dan Verifikasi data. Metode analisis data yang digunakan adalah analisis data dengan menggunakan metode yuridis kualitatif dan preskriptif yang berpedoman pada metode interpretasi dan konstruksi sesuai dengan teori, asas, dan kaidah hukum yang berkaitan dengan permasalahan yang di teliti.

\section{B. Hasil dan Pembahasan}

1. Terjadinya Perbedaan Pandangan dan Pengetahuan Mengenai Pernikahan Hamil di Luar Nikah Antara KHI dan Hukum Islam

Negara Indonesia merupakan negara hukum yang mayoritas penduduknya beragama Islam adalah merupakan realitas sosial, karena itu sangat relevan apabila hukum Islam dijadikan sumber rujukan dalam pembentukan hukum-hukum nasional. Maka peran ulama dan ilmuwan yang concern terhadap Islam sangat diperlukan (Tono, Muttaqien, 1999:1) (Muttaqien, Dadan \& Tono, Sidik(Ed),1999)

Berangkat dari pemahaman bahwa Islam adalah agama yang kaffah dalam segala hal dibandingkan dengan agama yang 
lainnya, maka di sinilah dibutuhkan sebuah kreatifitas bagi penganutnya untuk menggali ajaran-ajaran yang ada untuk terus dikembangkan agar eksistensi agama tidak hilang atau mati. Pembaharuan-pembaharuan dilakukan yang pasti tidak menyimpang dari tujuan syari'ah. Dengan demikian proses perkembangannya tidak menyalahi pesan yang ingin disampaikan oleh ajaran Islam. Juga mengingat di dalam Islam tidak hanya ada ajaran ketuhanan atau teologi akan tetapi juga ada dimensi hukum yang memperbaiki hubungan antara individu, masyarakat.

Kompilasi Hukum Islam merupakan hukum materiil dari salah satu di antara hukum positif yang berlaku di Indonesia. Berlakunya Kompilasi Hukum Islam tersebut berdasarkan: Instruksi Presiden No.1 Tahun 1991 tanggal 10 Juni 1991. Disebutkan bahwa kompilasi ini dapat dipergunakan sebagai pedoman dalam penyelesaian masalahmasalah di bidang yang diatur oleh kompilasi, yaitu hukum perkawinan, kewarisan, perwakafan oleh instansi pemerintah dan masyarakat yang memerlukannya.

Kebutuhan akan adanya KHI di Indonesia sebagai upaya memperoleh kesatuan hukum dalam memeriksa dan memutuskan perkara bagi para hakim di lingkungan peradilan agama, sudah lama dirasakan oleh Departemen Agama. Bahkan sejak adanya peradilan agama di Indonesia, keperluan ini tidak pernah hilang, bahkan berkembang terus sejalan dengan perkembangan badan. Latar belakang penyusunan KHI yang tidak mudah untuk dijawab secara singkat. Pembentukan KHI ini mempunyai kaitan yang erat sekali dengan kondisi hukum Islam di Indonesia ketika itu. Hal ini penting untuk ditegaskan mengingat sampai saat ini belum ada suatu pengertian yang disepakati tentang hukum Islam, yang masing-masing dilihat dari sudut pandang yang berbeda.

Kehadiran KHI di Indonesia merupakan suatu rangkaian sejarah hukum nasional yang merupakan makna kehidupan masyarakat Islam Indonesia yang diantaranya adanya norma hukum. KHI ini disepakati oleh para Alim Ulama Indonesia, bahkan KHI juga merupakan suatu rangkaian hukum tertulis dan masuk dalam Tata Hukum Indonesia melalui instrument Inpres No. 1/1991, kehadiran KHI merupakan sebuah alternatif dan tidak harus disepakati oleh para hakim agama dalam menerima, memeriksa, mengadili dan menyelesaikan suatu perkara yang diajukan padanya.

Hukum materiil yang selama ini berlaku di lingkungan Peradilan Agama ialah Hukum Islam yang dalam garis besarnya meliputi bidang-bidang hukum Perkawinan, Hukum Kewarisan, dan Hukum Kewakafan. Hukum materiil tersebut tertulis antara lain dalam kitab-kitab fiqih yang banyak beredar di Indonesia. Berdasarkan Surat Edaran Kepala Biro Peradilan Agama No.B/1/735 tanggal 18 Pebruari 1958, kitab-kitab fiqih yang dijadikan pedoman hukum tersebut ialah bersumber pada 13 buah kitab fiqih yang semuanya bermazhab Syafi'i.

Dadang Hermawan dan Sumardjo (Dadang Hermawan dan Sumardjo, 2015) menjelaskan bahwa inpres dan Keputusan Menteri Agama, KHI ini mempunyai kedudukan sebagai "pedoman" dalam putusan. Artinya sebagai petunjuk bagi hakim Pengadilan Agama dalam memutuskan dan menyelesaikan perkara, tergantung sepenuhnya kepada hakim untuk menggunakannya dalam putusan mereka masing-masing, sehingga KHI ini akan terwujud dan mempunyai makna serta landasan yang kokoh dalam yurisprudensi peradilan agama. Dengan demikian, maka hakim peradilan agama sekarang hanya berkewajiban menerapkan ketentuanketentuan yang sudah ada atau yang sudah digariskan dalam KHI, akan tetapi hakim mempunyai peranan yang lebih besar lagi untuk mengembangkan dalam melengkapinya melalui putusan yang dibuatnya.

Sebagaimana ditegaskan oleh Prof. Islamil Sunni dalam Dadang Hermawan dan Sumardjo (Dadang Hermawan dan Sumardjo, 2015) KHI sebagai pedoman, landasan dan pegangan para hakim-hakim di Peradilan Agama, Pengadilan Tinggi dan Hakim-hakim Mahkamah Agung dalam memeriksa dan 
memutuskan perkara-perkara yang menjadi wewenang Peradilan Agama. Sedang bagi masyarakat yang memerlukan dapat digunakan dalam kehidupan sehari-hari sesuai dengan kesadaran hukumnya untuk melaksanakan baik dalam bidang perkawinan, pembagian warisan, kegiatan amal ibadah dan sosial kemasyarakatan dalam perwakafan, disamping peraturan perundang-undangan yang lain, terutama sumber hukum Al-Qur'an dan Hadits.

Kekuatan KHI dijadikan sebagai sumber hukum materiil dilandasi oleh Inpres No. 1/1991 tentang Kompilasi Hukum Islam itu dasar hukumnya adalah pasal 4 ayat (1) UUD 1945, yaitu "Kekuasaan Presiden untuk memegang Pemerintahan Negara". Juga sebagaimana telah dijelaskan di BAB II dimana sumber hukum KHI yang salah satunya adalah Al-Qur'an dan Hadits yang tidak perlu diragukan lagi kekuatannya.

Menurut Austin hukum harus dipahami dalam arti perintah karena hukum seharusnya tidak memberi ruang untuk memilih (apakah mematuhi atau tidak mematuhi). Hukum bersifat non optional. Karena itu, mengkritik para penganut teori hukum kodrat Austin menegaskan bahwa hukum bukan setumpuk peraturan atau nasihat moral. Hukum dalam arti terakhir ini tidak punya implikasi hukuman apapun. Ketika hukum tidak lagi dapat dipaksakan, yakni pelanggarannya dikenai hukuman atau sanksi hukum, maka hukum tidak lagi dapat disebut hukum; atau hukum kehilangan esensinya sebagai perintah. Dengan demikian, kepatuhan pada hukum adalah kewajiban yang tidak dapat ditawar-tawar. Menyebut perintah sebagai hukum tetapi dalam praktek tidak dapat ditegakkan melalui penerapan sanksi hukum adalah absurd, karena hukum yang demikian tidak mampu memenuhi fungsi sosialnya sebagai alat kontrol terhadap tingkah laku masyarakat. Padahal, demikian Austin, mengontrol perilaku masyarakat adalah fungsi utama hukum. Dalam arti ini, sebetulnya Austin sepakat dengan Aquinas yang juga melihat hukum sebagai alat kontrol sosial. Akan tetapi, berbeda dengan Aquinas yang melihat hukum tertuma sebagai hasil kerja rasio, Austin justru menekankan watak perintah hukum yang bersumber pada kedaulatan penguasa. Dalam arti ini, pandangan hukum Aquinas lebih lunak dibandingkan dengan pandangan.

Hukum sebagai perintah, menurut Austin, memuat dua elemen dasar. Pertama, hukum sebagai perintah mengandung pentingnya keinginan, yakni keinginan dari seorang penguasa bahwa seseorang harus melakukan atau menahan diri untuk tidak melakukan sesuatu. Tentu saja, tidak semua keinginan mempunyai kekuatan sebagai hukum. Kalau saya ingin makan, misalnya, keinginan seperti ini pasti bukan hukum sifatnya. Karena itu, keinginan dalam arti hukum memiliki kekhususan, yakni bahwa "pihak yang terkena hukum harus menanggung akibat yang tidak menyenangkan atau membahayakan dari yang lain apabila gagal memenuhi hukum yang berlaku." Dengan demikian, hukum dalam arti perintah yang mengungkapkan keinginan penguasa pada dasarnya memuat ancaman hukuman bagi siapa pun yang berada di bawah hukum yang berlaku. Kedua, hukum memiliki kemampuan untuk menciptakan sesuatu yang tidak menyenangkan atau bahkan membahayakan subjek yang melanggarnya. Individu yang terkena perintah dengan sendirinya terikat, wajib berada dibawah keharusan untuk melakukan apa yang diperintahkan. Kegagalan memenuhi tuntutan perintah akan berakibat bahwa subjek yang terkena perintah mendapat sanksi hukum (Ujan) (Andre Ata Ujan, 2009).

Para ulama menggunakan dalil Alquran dalam menentukan hukum status pernikahan wanita hamil, terutama bagi Imam Hanafi dan Imam Syafi'i, yaitu memahami Alquran pada surah An-Nur ayat 3. Pandangan mazhab Maliki tentang hukum perkawinan dengan wanita hamil karena zina pada dasarnya membedakan antara perkawinan wanita hamil karena zina dengan laki-laki yang menghamilinya dan perkawinan wanita hamil karena zina dengan laki-laki yang tidak menghamilinya. Dalam kasus yang pertama, mazhab Malik memperbolehkannya, hal ini 
berdasarkan pada surat an-Nur ayat 3. Lebih jauh ditegaskan bahwa, jika anak dalam kandungan wanita tersebut lahir sesudah enam bulan terhitung sejak dilakukan akad nikah, nasabnya ditetapkan kepada laki-laki yang menghamili dan sekaligus menikahinya. Tetapi, jika anak dalam kandungan wanita tersebut lahir kurang dari enam bulan terhitung sejak dilakukan akad nikah, nasab anak yang lahir itu hanya ditetapkan kepada ibunya, tidak kepada ayahnya, kecuali lakilaki yang menghamilinya sekaligus menikahi wanita hamil tersebut mengaku bahwa anak yang lahir itu sebagai anaknya (Wahbah azZuhailii, 1985).

Sementara itu KHI yang secara khusus dalam babnya mengatur pernikahan wanita hamil, yaitu bab VIII pasal 53 ayat (1), (2), dan (3), di dalamnya ditetapkan bahwa "wanita hamil di luar nikah dapat di nikahkan dengan laki-laki yang menghamilinya tanpa harus menunggu kelahiran anak yang ada dalam kandungannya terlebih dahulu, dan perkawinan saat hamil tidak diperlukan lagi perkawinan ulang setelah anak yang dikandungnya lahir".

Dengan demikian perkawinan wanita hamil di luar nikah di tetapkan oleh KHI, bahwa wanita hamil di luar nikah dapat dikawinkan dengan laki-laki yang menghamilinya, dan dapat ditafsirkan pula kata "dapat" bahwa wanita hamil di luar nikah dapat di kawinkan dengan laki-laki lain yang tidak menghamilinya.

Berarti perkawinan wanita hamil di luar nikah boleh dilakukan baik dengan laki-laki yang menghamilinya ataupun laki-laki lain yang tidak menghamilinya yang ingin bertanggungjawab terhadap wanita tersebut, karena bisa jadi kehamilan itu bukan atas dasar perbuatan zina melainkan pemerkosaan terhadapnya yang dilakukan oleh laki-laki yang tidak jelas keberadaannya.

Oleh sebab itu, wanita hamil di luar nikah boleh di nikahkan dengan laki-laki manapun yang mau bertanggungjawab, karena apabila wanita hamil tidak dapat di nikahkan dengan laki-laki lain yang tidak menghamilinya sedangkan laki-laki yang menghamilinya tidak bertanggungjawab, dan tidak dilaksanakannya pernikahan dalam batas-batas tertentu menimbulkan dampak psikologis bagi keluarga wanita tersebut.

Secara rinci alasan perbedaan pendapat mengenai pernikahan hamil di luar nikah antara KHI dengan Hukum Islam. Peneliti uraikan pada tabel sebagai berikut:

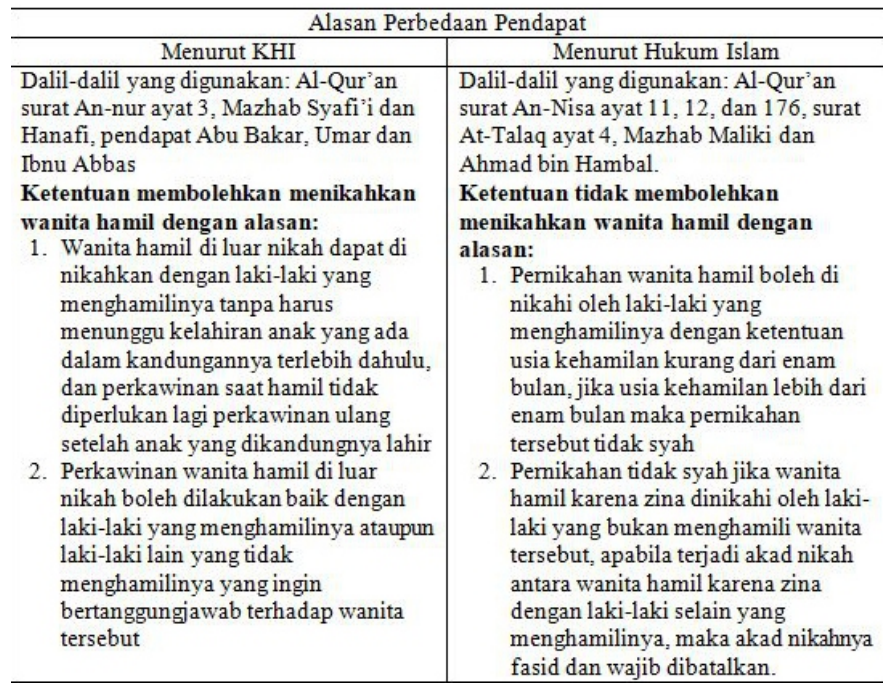

Berdasarkan tabel tersebut di atas dapat diketahui bahwa perbedaan pendapat mengenai pernikahan hamil di luar nikah antara KHI dengan Hukum Islam terjadi karena di pengaruhi oleh perbedaan dalil-dalil (Al-Qur'an dan Hadis) yang digunakan dalam menafsirkan permasalahan pernikahan hamil di luar nikah. KHI menjelaskan pernikahan hamil di luar nikah berdasarkan dalil AlQur'an surat An-nur ayat 3, Mazhab Syafi'i dan Hanafi, pendapat Abu Bakar, Umar dan Ibnu Abbas. Sedangkan Hukum Islam menggunakan dalil Al-Qur'an surat An-Nisa ayat 11,12 , dan 176, surat At-Talaq ayat 4, Mazhab Maliki dan Ahmad bin Hambal.

\section{Status Hukum Pernikahan Wanita Hamil Akibat Zina dengan Laki-laki yang Menghamilinya Menurut KHI dan Hukum Islam}

Kasus kawin hamil di luar nikah secara khusus diatur dalam Pasal 53 KHI. Pasal tersebut menjelaskan tentang kebolehan melangsungkan perkawinan bagi wanita hamil di luar nikah. Meskipun demikian, ada ketentuan yang harus dipenuhi dalam perkawinan tersebut, diantaranya: (1) Seorang wanita hamil di luar nikah bisa 
dikawinkan dengan pria yang menghamilinya; (2) Perkawinan dengan wanita hamil yang disebut pada ayat (1) dapat dilangsungkan tanpa menunggu lebih dahulu kelahiran anaknya; (3) Dengan dilangsungkannya perkawinan pada saat wanita hamil, tidak diperlukan perkawinan ulang setelah anak yang dikandung lahir.

Ketentuan Pasal 53 KHI tentang kebolehan melangsungkan perkawinan bagi wanita hamil ini bisa dikategorikan kontroversial karena akan melahirkan perdebatan dan silang pendapat dari berbagai kalangan. Pendapat yang kontra tentu akan merasa keberatan dengan ketentuan ini yang dinilai longgar dan cenderung kompromistis. Bisa dimungkinkan ketentuan ini justru akan dijadikan payung hukum legalisasi perzinaan.

Pasal 53 KHI tersebut tidak memberikan sanksi atau hukuman bagi pezina, melainkan justru memberi solusi kepada seseorang yang hamil akibat perzinaan itu untuk segera melangsungkan perkawinan. Padahal dalam fiqh telah dijelaskan perihal hukuman terhadap pelaku zina, diantaranya: jika pelaku zina itu sudah menikah (zina muhsan) hukumannya adalah didera seratus kali dan kemudian dirajam. Bagi pelaku zina yang belum menikah (zina ghairu muhsan) hukumannya adalah didera seratus kali dan kemudian diasingkan ke tempat lain selama satu tahun (Asy Syaukani, 1994: 550).

Kendati demikian, ketentuan Pasal 53 KHI tersebut juga berpegangan pada alasan logis dan bisa dijadikan landasan hukum untuk diterapkan dalam tatanan kehidupan masyarakat di Indonesia. Kebolehan melangsungkan perkawinan bagi wanita hamil menurut ketentuan Pasal 53 KHI, secara tegas dibatasi pada perkawinan dengan laki-laki yang menghamilinya.Hal tersebut berlandaskan pada firman Allah SWT dalam surat An-Nur ayat 3 yang Artinya "Laki-laki yang berzina tidak mengawini melainkan perempuan yang berzina, atau perempuan yang musyrik. Dan perempuan yang berzina tidak dikawini melainkan laki-laki yang berzina atau laki-laki yang musyrik. Dan yang demikian itu diharamkan atas orang-orang
mukmin”(Q.S. An-Nur: 3). Istilah perkawinan wanita hamil adalah perkawinan seorang wanita yang sedang hamil dengan laiki-laki sedangkan dia tidak dalam status nikah atau masa iddah karena perkawinan yang sah dengan laki-laki yang mengakibatkan kehamilanya.

Mengenai ketentuan-ketentuan hukum perkawinan wanita hamil dalam pendapat para imam mazhab (Hanafi, Malik, Syafi'i dan Ahmad bin Hambal), mereka berbeda pendapat, pada umumnya dikelompokkan kepada dua kelompok pendapat:

a. Imam Hanafi dan Imam Syafi'i mengatakan:

Wanita hamil akibat zina boleh melangsungkan perkawinan dengan laki-laki yang menghamilinya atau dengan laki-laki lain. Sebagaiman pendapat imam Hanafi sebagai berikut: "Wanita hamil karena zina itu tidak ada iddahnya, bahkan boleh mengawininya, tetapi tidak boleh melakukan hubungan seks hingga dia melahirkan kandungannya". Sementara Imam Syafi'i mengatakan: " hubungan seks karena zina itu tidak ada iddahnya, wanita yang hamil karena zina itu boleh dikawini, dan boleh melakukan hubungan seks sekalipun dalam keadaan hamil".

Menurut mereka wanita zina itu tidak dikenakan ketentuan-ketentuan hukum perkawinan sebagaimana yang ditetapkan dalam nikah. Karena iddah itu hanya ditentukan untuk menghargai sperma yang ada dalam kandungan isteri dalam perkawinan yang sah. Sperma hasil dari hubungan seks di luar nikah tidak ditetapkan oleh hukum.

Mereka beralasan dengan Al-quran pada surah An-Nur ayat 3 "Laki-laki yang berzina tidak mengawini melainkan perempuan yang berjina, atau perempuan musyrik; dan perempuan yang berzina tidak dikawini melainkan oleh laki-laki yang berzina atau laki-laki musyrik".

Menurut Imam Hanafi meskipun perkawinan wanita hamil dapat dilangsungkan dengan laki-laki, tetapi dia tidak boleh disetubuhi, sehingga bayi yang dalam kandungan itu lahir. Ini didasarkan 
pada sabda Nabi Muhammad SAW yang artinya: Janganlah kamu melakukan hubungan seks terhadap wanita hamil sampai dia melahirkan.

Menurut Imam Syafi'i perkawinan wanita hamil itu dapat dilangsungkan, dapat pula dilakukan persetubuhan denganya, ini didasarkan pada sabda Nabi Muhammad SAW yang artinya "Bagi dia maskawinya, karena kamu telah meminta kehalalanya untuk mengumpulinyasedang anak itu hamba bagimu"...

Memperhatikan imam Syafi'i maka seorang wanita hamil karena hasil melakukan hubungan seks di luar nikah jika dia melangsungkan perkawinan dengan laki-laki, maka kehamilan itu tidak mempengaruhi dalam perkawinannya.

Jika memperhatikan pendapat imam Hanafi, meskipun boleh wanita hamil melangsungkan perkawinan dengan seorang laki-laki, tetapi dia dilarang melakukan hubungan seksual. Dilarangnya wanita hamil melakukan hubungan seksual dengan lakilaki yang mengawininya, berarti kehamilanya mempengaruhi terhadap kelangsungan kehidupan rumah tangganya, sebagaimana layaknya orang yang kawin.

b. Imam Malik dan Ahmad bin Hambal mengatakan

Tidak boleh melangsungkan perkawinan antara wanita hamil karena zina dengan laki-laki lain sampai dia melahirkan kandungannya.

Menurut Imam Malik dan Ahmad bin Hambal sama halnya dengan yang dikawini dalam bentuk zina atau syubhat atau kawin pasid, maka dia harus mensucikan diri dalam waktu yang sama dengan iddah. Untuk mendukung pendapatnya mereka mengemukakan alasan dengan sabda Nabi Muhammad SAW yang artinya: "Tidak halal bagi seorang yang beriman kepad Allah dan hari akhirat mmenyiramkan airnya (spermanya) kepada tanaman orang lain, yakni wanita-wanita tawanan yang hamil, tidak halal bagi seorang yang beriman kepada Allah dan hari akhirat mengumpuli wanita tawanan perang sampai menghabiskan istibra'-nya (iddah) satu kali haid.
Mereka juga beralasan dengan sabda Nabi Muhammad SAW yang lainya: "Jangan kamu menggauli wanita hamil sampai dia melahirkan dan wanita yang tidak hamil sampai haid satu kali”.

Imam Malik dan Imam Ahmad bin Hambal mengambil kesimpulan dari kedua hadis tersebut, bahwa wanita hamil tidak boleh dikawini, karena dia perlu iddah. Mereka memberlakukan secara umum, termasuk wanita hamil dari perkawinan yang sahh, juga wanita hamil dari akibat perbuatan zina.

Adanya penentuan larangan perkawinan wanita hamil tersebut berawal dari pendapat mereka yaitu, wanita hamil karena zina tetap memiliki iddah, maka wanita hamil tidak boleh melangsungkan perkawinan sampai dia melahirkan kandungannya. Dengan demikian wanita hamil dilarang melangsungkan perkawinan.

Bahkan menurut Imam Ahmad bin Hambal, wanita hamil karena zina harus bertaubat, baru dapat melangsungkan perkawinan dengan laki-laki yang mengawininya. Pendapat kedua Imam ini dapat dimengerti agar menghindari adanya percampuran keturunan, yaitu keturunan yang punya bibit dan keturunan yang mengawini ibunya.

Oleh karena itu imam Malik dan Ahmad bin Hanbal memberlakukan iddah secara umum terhadap wanita hamil, apakah hamilnya itu karena perkawinan yang sah, ataukah kehamilanya itu akibat dari hubungan seksual di luar nikah. Dengan demikian perkawinan wanita hamil dilarang.

\section{Status Nasab Anak Dalam Pernikahan Wanita Hamil}

Adapun status nasab anak dari pernikahan wanita hamil, para imam mazhab berbeda pendapat: (1) Para ulama sepakat bahwa anak akibat zina itu tidak dinasabkan kepada ayahnya, tetapi dinasabkan kepada ibunya. Sebagaimana yang dijelaskan oleh Ibnu Rusyd dalam kitab Bidayatul Mujtahid bahwa "ulama telah sepakat bahwa anak akibat zina itu tidak dinasabkan kepada ayahnya, kecuali yang terjadi di zaman jahiliyah"; (2) Imam Syafi'i berpendapat, 
paling cepat umur kehamilanya itu adalah enam bulan, apabila perkawinan telah lebih dari enam bulan, lalu anak lahir, maka anak tersebut mempunyai hubungan nasab kepada suaminya. Sebaliknya apabila kurang dari enam bulan, maka nasab anak tersebut dihubungkan kepada ibunya.Ibnu Rusyd mengatakan bahwa Imam Syafi;i berkata: "Siapapun yang kawin dengan seorang wanita dan belum mencampurinya atau telah mencampurinya sesudah akad, lalu wanita itu melahirkan anak setelah enam bulan dari waktu terjadinya akad bukan dari waktu terjadinya percampuran itu, maka anak tersebut tidak dipertalikan nasabnya kepada seorang laki-laki yang mengawini, kecuali jika ibu itu melahirkan setelah lebih dari enam bulan.Pendapat tersebut jika diperhatikan dengan pengertian dari perkawinan (nikah) itu sendiri secara istilah, yaitu nikah adalah akad penghalalan persetubuhan. Oleh karena itu konsekuensinya, jika seorang wanita ternyata hamil sebelum akad dimaksud, maka kehamilan wanita tersebut tidak dihargai, bibit itu dapat milik laki-laki mana saja, sebab itu apabila anak itu lahir, dia tidak memiliki nasab kepada laki-laki (ayah), tetapi hanya memiliki nasab kepada ibunya; (3) Imam Hanafi berpendapat bahwa anak yang dilahirkan oleh wanita hamil dengan laki-laki atau suami, maka hubungan anak tersebut dengan suami ibunya. Dengan demikian menurut imam Hanafi, bahwa setiap anak yang lahir akan dihubungkan nasabnya kepada laki-laki yang memiliki bibit. Ketentuan ini terlihat dengan sikapnya mengartikan nikah dengan setubuh. Maka konsekuensinya asal terjadi hubungan seksual yang mengakibatkan lahirnya seorang bayi, maka bayi tersebut adalah anak laki-laki pelaku perbuatan zina tersebut. Dengan demikian, bayi yang lahir dari perkawinan wanita hamil itu bukan secara langsung dinasabkan kepada laki-laki yang mengawini ibunya bayi, tetapi dmasabkan kepada mereka yang menuai bibit, artinya bisa pula dinasabkan kepada orang yang bukan mengawini ibu bayi tersebut.

\section{Simpulan}

Berdasarkan uraian di atas, maka dapat disimpulkan sebagai berikut:

1. Perbedaan mengenai pernikahan hamil di luar nikah antara KHI dan hukum Islam. Menurut KHI bahwa wanita yang hamil di luar nikah bisa langsung di nikahkan dengan laki-laki yang menghamilinya tanpa menunggu wanita itu melahirkan kandugannya. Sedangkan berdasarkan hukum Islam dalam hal ini pendapat Imam Malik dan Ahmad bin Hambali yang mengatakan tidak boleh melangsungkan pernikahan antara wanita hamil karena zina dengan laki-laki sampai dia melahirkan kandungannya. Perbedaan tersebut terjadi karena di pengaruhi oleh perbedaan dalil-dalil (Al-Qur'an dan Hadis) yang digunakan dalam menafsirkan permasalahan pernikahan hamil di luar nikah. KHI menjelaskan pernikahan hamil di luar nikah berdasarkan dalil Al-Qur'an surat Annur ayat 3, Mazhab Syafi'i dan Hanafi, pendapat Abu Bakar, Umar dan Ibnu Abbas. Sedangkan Hukum Islam menggunakan dalil Al-Qur'an surat AnNisa ayat 11, 12, dan 176, surat AtTalaq ayat 4, Mazhab Maliki dan Ahmad bin Hambal.

2. Status hukum pernikahan wanita hamil akibat zina dengan laki laki yang menghamilinya. KHI membolehkan menikahi wanita hamil akibat zina dengan laki-laki yang menghamilinya, menurut hukum Islam status hukum pernikahan wanita hamil akibat zina dengan laki-laki yang menghamilinya pun terjadi perbedaan pendapat diantara ke empat mazhab. Mazhab Hanafi dan Syafi'i membolehkan pernikahan wanita hamil akibat zina dengan lakilaki yang menghamilinya. Mazhab Maliki dan Hanbali melarang pernikahan wanita hamil akibat zina dengan laki-laki yang menghamilinya.

Saran yang penulis berikan yaitu:

1. Pembahasan mengenai hukum 
perkawinan akibat hamil di luar nikah sangatlah luas, karena itu diharapkan untuk penelitian selanjutnya akan menghasilkan penelitian yang lebih luas dan mendalam. Pembahsan tersebut agar selalu dicari relevansinya dengan perkembangannya masa kini, agar penelitian tersebut tidak hanya menjadi bahan bacaan namun bisa menjadi rujukan sumber hukum yang jelas.

2. Menghadapi perkembangan zaman yang semakin pesat dan terjadinya degradasi moral terutama dikalangan remaja, diharapkan agar para orang tua selalu menanamkan nilai-nilai agama kepada putra putrinya sedini mungkin, sehingga dapat meminimalisasi terjadinya perkawinan akibat hamil di luar nikah.

\section{DAFTAR PUSTAKA}

Andre Ata Ujan, Filsafat Hukum Membangun Hukum, Membela Keadilan, Kanisius, 20009 . O n 1 i n e : h t t p s : / / artnur.wordpress.com/2010/03/13/posi tivisme-hukum-john-austin-17901859/. Di akses pada tanggal 3 Juni 2017. Pukul 13.00 WITA.

Ash-Shiddieqy, Hasbi. 1978. Hukum-Hukum Fiqih Islam. Jakarta: Bulan Bintang hlm. 265

Dadang Hermawan dan Sumardjo (2015). Kompilasi Hukum Islam Sebagai Hukum Materiil Pada Peradilan Agama. Jurnal Yudisia Vol. 6 Nomor 1, J u n i 2015 . On $1 \mathrm{ine}$. file:///C:/Users/Windows7-ultimate/ Downloads/1469-4905-1-PB.pdf. Di akses pada tanggal 3 Juni 2017, Pukul 10.30 WITA.

Departemen Agama RI. 2000. Kompilasi Hukum Islam Di Indonesia. Bandung : Fokusmedia hlm.14

Khoirudin Nasution, Islam; Tentang Relasi Suami dan Istri (Hukum Perkawinan I) (Yogyakarta: ACADEM IA, dan Tazzafa, 2004), hlm. 35-50.

Muttaqien, Dadan. \& Tono, Sidik (Ed).1999. Peradilan Agama dan Kompilasi Hukum Islam. Yogyakarta: UII Press.
H $1 \mathrm{~m}$. 1. Tersedia pada: file:///C:/Users/Windows 7 ultimate/Downloads/1469-4905-1PB.pdf.

Qardhawi, Yusuf. 2003. Halal Haram Dalam Islam. Solo: Era Intermedia hlm. 214216

Undang-Undang Dasar Negara Republik Indonesia Tahun 1945 dan Perubahannya

Undang-undang Republik Indonesia Nomor 1 tahun 1974 tentang Perkawinan. Lembaran Negara Republik Indonesia 1974 Nomor 1

Wahbah az-Zuhailii, al-Figh al-Islami wa adillatuhu (Beirut: Dar al Fikr, 1985) VII: 148 